\title{
SISTEM MANAJEMEN ORGANISASIONAL PERUSAHAAN KERAJINAN KULIT DALAM MEMENUHI KEBUTUHAN PASAR
}

Tugimin (Tugiminatk123@yahoo.co.id)

DPTK, Akademi Teknologi Kulit Yogyakarta

\begin{abstract}
Organizational management system combines all management functions within an organization's productive holistically built based on the concept of quality, teamwork, productivity and customer satisfaction. Be as creative industries leather craft is required to follow the changes and able to meet the needs of the market. Change the orientation of the market take effect directly against the durability of micro, small and medium-sized leather craft, it takes a flexible company management system in maintaining continuity of effort, that it took creativity and innovation on an ongoing basis. Among the many leather companies in Yogyakarta were selected for this study are "CV D \& D Leather Handycraft". Through kuantitatif research method system of organizing the company confirms that the craft's skin, between the interelasi policy (team work) in organizational management system is determined by the ability of human resources creative and innovative.
\end{abstract}

Key word : A system of organizing, human resources, fulfillment of market needs

\section{PENDAHULUAN}

Yogyakarta merupakan kota industri kreatif, jenis kerajinan yang disini menyesuaikan permintaan akan produk tertentu (trend pasar), namun setiap pergeseran trend pasar tersebut akan berdampak pada timbul tenggelamnya sejumlah usaha mikro, kecil dan menengah (UMKM) di Yogyakarta. Ada banyak faktor yang menyebabkan hal itu terjadi, diantara faktor yang paling dominan adalah faktor kreasi dan inovasi yang bertumpu pada kemampuan sumber daya manusia. Sehingga semua sektorkerajinan dituntut mampu menampilkan motif - motif baru yang memiliki nilai jual yang diminati konsumen. Begitu juga dengan kerajinan sepatu dan tas kulit dituntut untuk mampu menciptakan kreasi baru berbahan karet, kuningan, kayu, keramik, dan seterusnya.

Keberhasilan perusahaan kerajinan kulittidak semata - mata bertumpu pada faktor eksternal seperti halnya minat konsumen saja, tetapi factor internal justru memegang peranan penting dan menyeluruh. Dalam hal ini sistem manajemen organisasional merupakan faktor inti dari serangkaian sistem kerja yang terpadu secara menyeluruh, terkoordinasi secara rasional yang mampu mentransformasi kebijakan dalam meningkatkan produktivitas sesuai dengan seluruh rancangan kerja dan kriteria mutu yang telak ditetapkan (Pryor, M. G., Anderson, D., Toombs, L., \& Humphreys, J. H. 2007).

Bergesernya trend pasar yang terjadi di Yogyakarta dari trend terakota bergeser kearah trend batik, kemudian bergeser trend batik ke arah trend kayu, kemudian trend kayu bergeser ke arah trend kulit dan seterusnya. Akibat dari perubahan tersebut bagi 
UMKM yang tidak memiliki kemampuan mengikuti trend baru tersebut maka produksinya akan merosot tajam. Hal ini terjadi sebagai dampak perubahan global, untuk itu UMKM perlu didukung oleh kemampuan sumber daya manusia supaya mampu melakukan kreasi, inovasi dan improvisasi sehingga memiliki kemampuan menjalankan bisnis tersebut. Hal ini perlu menjadi perhatian bersama karena banyak UMKM masih mengalami permasalahan internal dan keterbatasan sumber daya manusia sehingga tidak memiliki kemampuan adaptive (Mengue, N. and S. Auh, 2006).

Sejauh ini UMKM industri kerajinan kulit di Yogyakarta banyak yang mengandalkan naluri bisnis, padahal dalam bisnis hal tersebut justru sangat beresiko, untuk itu sebaiknya sumber dayamanusianya perlu didorong agar mampu membaca dan mempelajari trend pasar. Hal tersebut perlu didukung melalui sistem organisasional perusahaan kerajinan kulit yang baik, salah satu contohnya di tunjukkan oleh perusahaan "CV D\&D Leather Craft" yang mampu bergerak cepat ditengah terpaan krisis yang sedang dialami. Salah satu kunci sukses perusahaan, ini adalah bagaimana mengelola suatu informasi untuk dapat dituangkan kedalam strategis pemasaran, dalam hal ini maka dituntut untuk mampu membaca dan memahami bagaimana perubahan informasi pasar itu terjadi. Dengan demikian dibutuhkan penguasaan informasi secara lengkap, sehingga setiap informasi yang dikumpulkan mampu dijadikan bahan analisa yang akan dituangkan sebagai strategi pemasaran yang baru, (Frismar, J. And Horte, S.A 2005).

Penerapan strategi pemasaran pada setiap perusahaan berbeda-beda, sehingga tingkat keberhasilan yang dicapai oleh masing-masing perusahaan juga akan berbedabeda. Keberhasilan membaca karakter pasar biasanya akan ditandai dengan meningkatnya permintaan barang terutama komoditi eksport dengan Brand Image yang melekat pada konsumen domestik maupun lintas negara seperti pangsa pasar Asia, Amerika Serikat, Australia dan Eropa. Dengan demikian akan menjadi sangat vital dalam menjaga kepercayaan demi keberlangsungan perusahaan.

Dalam menjaga kepercayaan, kesetiaan dankeyakinan konsumen maka harus disertai pelayananyang baik pula, dalam sistem pemasaran dituntut harus mampu menyediakan produk yang mudah diperoleh cepat sesuai harga dan jaminan kualitas yang lengkap dengan keunikannya.

Penelitian ini bertujuan untuk mengetahui sejauh mana penerapan sistem organisasional yang dilakukan oleh perusahaan kulit dalam menghadapi perkembangan trend pasar untuk mempersiapkan diri sehingga membentuk team-work yang mengandalkan sumberdaya manusia terhadap pemenuhan kebutuhan pasarnya.

\section{KAJIAN LITERATUR DAN HIPOTESIS}

Dalam tata kelola sistem organisiasional pemasaran produk industri kulit dalam hal ini seorang manajer pemasaran sangat penting memahami kondisi pasar sehingga 
butuh data informasi yang akan menjadi bahan pertimbangan dalam mengambil suatu keputusan. Setidaknya informasi yang dibutuhkanuntuk hal tersebut meliputi informasi trend pasar, struktur pasar yang ada, informasi harga dan sistem pembayaran, informasi produk dan pengembangan produk yang diperlukan semisal dalam hal trend dan desain, promosi dan informasi teknis distribusi secara fisik. Berbagai informasi mengenai kualitas, nilai dan brand image dan pelayanan yang baik ini akanmembentuk perilaku konsumen yang terpuaskan sehingga ada ikatan emosional terhadap produk yang ditawarkan sesuai kreasi dan inovasi baru yang disukai selera pasar (Cronin, Jr., JJ., Brady, M.K., \& Hult,G,T.M., 2000).

Sedangkan untuk sistem pemasaran dalam hal ini terutama mencakup target pasar, promosi dan harga, program pemasaran dan anggaran pemasaran. Biasanya ekspansi pasar akan disertai penjajagan pasar sebelumnya. Bila semua telah ditempuh maka akan diimbangi dengan pengendalian pasar, untuk itulah akan digelar promosi dan pemberian paket potongan maksimal $20 \%$ sebagai strategi pemasaran dengan alasan untuk mengejar target pemenuhan jumlah pemasaran seperti yang telah direncanakan sebelumnya. Sedangkan pertimbangan multi faktor yang lain adalah dalam bentuk catatan pertumbuhan ekonomi, peredaran uang, tingkat pembelanjaan dan inflasi, selain itu juga kebijakan fiskal dan moneter dan stabilitas politik dan perekonomian suatu bangsa.

Iklim persaingan juga menarik untuk dilihat karena seringkali justru muncul terobosan - terobosan baru yang perlu dipertimbangkan juga. Strategi terakhir biasanya melalui "marketing mix" untuk menciptakan "brand image" terhadap konsumen selain faktor kualitas produk, harga, distribusi dan meningkatkan reputasi produk melalui promosi.

Bilamana keadaan sudah jenuh maka perlu dilakukan upaya untuk memperbaharui pandangan untuk menggiring konsumen yaitu melalui cara merubah barang menjadi eksklusif atau baru, model khusus segmen tertentu, penyederhanaan model untuk kelas ekonomi dan menambah assesories untuk menambah daya tarik lainnya. Selain itu packing, merek dan pelayanan yang menarik. Kondisi ini menandakan bahwa trend pasar bisa berubah, maka inovasi dan kreasi desain baru diharapkan mampu mengantisipasi kejenuhan pasar sehingga selalu ada nuansa baru sehingga tetap memiliki prospek usaha yang berkesinambungan (DirkC. Moosmayer, Alexandra Fuljahn, 2010).

Dari tingkat manajemen organisasional, semua bagian merupakan pilar kekuatan dalam memenangkan sebuah persaingan pasar, untuk itu perusahaan kerajinan kulit selalu mendorong motivasi kerjanya dalam bentuk pelatihan peningkatan ketrampilan bagi karyawan agar dapat berprestasi. Kebijakan dalam proses perencanaan pengelolaan internal sangatlah penting dalam memotivasi dalam hal pekerjaan. Disadari langkah ini memiliki peran ganda bahwa disatu sisi sebenarnya sangat bermotif bisnis, namun disisi 
yang lain memiliki spirit penghargaan terhadap peningkatan kesejahteraan karyawan (H. Teman Koesmono, 2005).

Semakin kompleks sistem organisasi maka semakin banyak hal yang dapat diakomodasi oleh perusahaan dan semakin besar pula investasi sumber daya manusia yang memiliki produktivitas melalui ketrampilan dan inovasi tinggi sekalipun itu terjadi dalam perusahaan keluarga. Keberhasilan perusahaan juga menuntut kompensasi yang adil atas terpenuhinya kebutuhan dasar bagi seluruh karyawan dalam bentuk kenaikan jenjang karir dan jabatan, sehingga perusahaan wajib memberikan ruang kebijakan sebagai bentuk penghargaan terhadap prestasi kerja karyawan, (Eddy, M.Susanto, 2003).

Kemampuan sumber daya manusia kreatif dan inovatif merupakan salah satu dasar yang membentuk keberhasilan suatu usaha, begitu juga dengan karakter sistem organisasional sedikit banyak terus mengalami perkembangan yang sangat luar biasa mulai dari penataan organisasi yang ramping dan sederhana akan berbeda dengan penataan organisasi yang diatur secara kompleks. Pola usaha yang berorientasi pasar sudah pasti mendasarkan produknya sesuai dengan tuntutan pasar dan salah satunya adalah mengintegrasikan penguasaan ketrampilan kerja modern dengan mempertahankan sentuhan tradisional, karena disadari bahwa inilah keunggulan komparatif produk yang dihasilkan untuk mampu berkompetisi sesuai yang diharapkan pasar. Manajemen pemasaran yang berorientasi pasar inilah yang selama ini perlu dikembangkan sebagai pijakan dasar, konsep dan strategi UMKM kerajinan kulit di Yogyakarta.

Proses perkembangan organisasional perusahaan kerajinan kulit biasanya bermula dari usaha keluarga yang sangat sederhana, kemudian bergeser membentuk pola usaha yang menyesuaikan tata aturan organisasional yang semakin sempurna, hingga secara menyeluruh membentuk unit usaha yang lengkap mulai dari sistem penerimaan pegawai, sistem administrasi produksi, sistem administrasi pemasaran. Dukungan sistem organisasional yang lengkap akan dapat diandalkan untuk memberi suporting sistem dalam pengembangan pemasaran secara global hal ini akan sangat berarti karena proses keseluruhan akan mempengaruhi Analisis, Perencanaan dan Pengendalian pemasaran suatu produk.

Penegasan hubungan interaksi kausal antara keberhasilan sistem pemasaran, lebih ditentukan oleh penataan sistem administrasi manajemen, sistem produksi barang yang ditentukan oleh sumber daya manusia yang kreatif dan inovatif sehingga mampu memenuhi permintaan kebutuhan pasar dengan baik. Sebagai suatu rangkaian inti dalam suatu sistem organisasional masing-masing memiliki interdependensi satu sama lain.

Terkait dengan hal tersebut, secara definitif sistem administrasi manajemen, produksi dan pemasaran merupakan satu rangkaian organisasional. Pendekatan sistemik dari suatusistem administrasi manajemen, produksi dan pemasaran secara menyeluruh menurut Webster's New Collegiate Dictionary, sistem semacam ini dapat didefinisikan 
sebagai "Interaksi secara teratur atau sekelompok bagian-bagian yang membentuk satu kesatuan secara menyeluruh". Sehingga dalam satu sistem terdapat bagian-bagian (subsistem) yangmembentuk menjadi satu kesatuan yang utuh yangmasing-masing bagian saling berhubungan danmemberikan pengaruh. Kalau diperhatikan mulai dari kualitas produksi kerajinan kulit maka akan sangat tinggi pula dampak pengaruhnya pada pandangan konsumen tantang kulit. Sebagai contoh, untuk menilai kualitas sebuah produksi kerajinan kulit yang dipertimbangkan adalah fungsi, praktis, kemudahan, pemakaian dan daya tahan.

Misalnya produk kerajinan kulit yang diintegrasikan dengan assesories berbahan rotan, kayu atau besi dalam pembuatan tas, akan sangat berbeda dengan pembuatan produk sepatu yang mengintegrasikan dengan karet dan tembaga pada pembuatan ikat pinggang. Hal tersebut didukung oleh kreasi dan inovasi seperti ditegaskan melalui penelitian yang menyatakan bahwa penentuan item-item pengukuran citarasa kualitas pada suatu produk akan sangat berbeda dengan produk dari industri kompetitor yang lain.

Dengan demikian maka aspek kualitas dalam hal ini memiliki hubungan erat dengan kepuasan konsumen. Kualitas memberikan suatu dorongankepada konsumen untuk menjalin ikatan hubunganyang kuat dengan perusahaan. Selain itu perusahaan juga dapat meningkatkan pangsa pasamya melalui pemenuhan kualitas yang bersifat customer driven. Hal ini akan memberikan keunggulan harga dan customer value (Tjiptono, 2000).

Memperhatikan aspek kepuasan konsumen ini adalah semacam langkah perbandingan antara pengalaman dengan hasil evaluasi, dapat menghasilkan sesuatu yang nyaman secaca emosional karena sesuai dengan apa yang dibayangkan atau diharapkan. Konsumen yang puas akan membeli "produk" lain yang dijual oleh perusahaan, sekaligus menjadi "pemasar" yang efektif melalui word of month yang positif. Peran perusahaan semacam ini dapat membantu meningkatkan penjualan dan kredibilitas perusahaaan. Sedangkan mengenai hasil keunikan, kerajinan kulit yang dikerjakan secara tradisional akan memiliki dua dimensi loyalitas konsumen, yaitu behavioral dan attitudinal (Hallowel, 1996; Dharmmesta, 1999).

Dimensi perilaku (behavioral) menunjukkan kesediaan konsumen untuk melakukan pembelian ulang pada merek atau penyedia jasa yang setiap waktu dan mereka merekomendasikan pada pihak lain, yang mencerminkan kesetiaan konsumen. Secara mendasar permasalahan diketahui bahwa yang dihadapi oleh para pelaku bisnis sektor kerajinan kulit ini bila trend pasarnya sepi sehingga tingkat perputaran modal menjadi rendah, maka kesabaran, keuletan, ketelitian, kreatifitas dan improvisasi dalam menerapkan kebijakan sangatlah dibutuhkan karena banyak pengusaha kecil disektor ini terjebak oleh masalah internal. Dengan demikian penataan sistem manajemen organisasional yang baik maka kemampuan adaptive akan sangat menunjang keberhasilaa suatu usaha diera global sekarang ini. 
Keberhasilan penerapan sistem organisasional suatu perusahaan memerlukan waktu yang lama, mulai dari usaha kerajinan kulit kecil-kecilan yang dikerjakan sendirian, sebagai contoh produksi "CV D \& D Leather craft" berawal dari usaha keluarga dengan modal Rp 10.000, pada tahun 1982 dimulailah produksi dompet kulit yang dipasarkan dikawasan Malioboro Yogyakarta.

Kemampuan membaca permintaan pasar maka dikembangkan desain-desain baru yang produksinya menjadi berlipat, maka disini mulai menambah karyawan baru, seiring dengan peningkatan investasi, pada tahun kedua telah mencapai

2.000.000, dimulailah pembagian kerja yang secara khusus menangani bagian tertentu dan pada tahun 1989 telah berkembang lagi menjadi Rp 26.000.000, dan pada tahun 2009 telah menjadi perusahaan industri kulit dan tas yang cukup besar yang mampu menerapkan sistem organisasi yang mampu menggabungkan semua fungsi manajemen dalam suatu organisasi berdasarkan konsep kualitas, teamwork, produktivitas dan kepuasan konsumen hingga menjadi perusahaan besar sehingga mampu memasuki pasar global.

Dengan organisasi yang lengkap, maka mampu mencakup seluruh bagian penting mulai dari pimpinan, sekretaris, bagian personalia, bagian keuangan, bagian produksi (ditambah subbag produksi, pelaksana) dan bagian pemasaran (ditambah bagian export dan retailer). Sebagai bagian dari organisasional masing-masing bagian memiliki tugas dan kewenangannya masing-masing. Seperti halnya tugas pimpinan adalah koordinator inti organisasional, berhak untuk mengeluarkan kebijakan yang menguntungkan perusahaan, memberikan arahan dan bimbingan dalam tata laksana organisasional dan menyusun strategis, dan negosiator dengan berbagai pihak perusahaan.

Begitu pula dengan bagian sekretaris memiliki kewenangan seluruh catatan urusan perusahaan, mulai dari urusan inventaris, data seluruh mitra, urusan barang keluar masuk, maupun urusan surat menyurat. Sedangkan bagian produksi dalam hal ini memiliki kewenangan desain, produksi sesuai jumlah pesanan, mengatur proses produksi, bertanggung jawab atas hasil produksi, mencatat dan memperhitungkan ketersediaan bahan baku. Bagian personalia memiliki kewenangan rekruitmen dan pemberhentian karyawan, menentukan besaran upah, bertanggung jawab dalam hal urusan peningkatan sumber daya manusianya. Bagian keuangan memiliki kewenangan perencanaan dan kontrol keluar masuknya keuangan perusahaaa serta perencanaan upah. Sedangkan bagian pemasaran memiliki kewenangan menentukan program pemasaran, pembelian langsung pada perusahaan, promosi dan urusan pendistribusian produk yang akan dikirimkan pada konsumen diwilayah tujuan pemasaran. Sedangkan personalia dalam hal ini lebih banyak menyesuaikan jumlah permintaan barang karena dalam pelaksanaannya relatif fleksible, pengaturan sistem jam kerja, sistem pengupahan, asuransi, dan penerapan harga barang, penetapan belanja rutin dan penggajian rutin pegawai. Berbagai faktor eksternal telah berperan membesarkan usaha 
ini sangat dipengaruhi oleh faktor kepercayaan konsumen yang telah mempercayainya (Miyazaki, A., Grewal, D. \& Goodstein, R,, 2005).

Pengukuran kinerja merupakan alat perolehan data untuk membantu mengkoordinasi proses pengambilan keputusan diseluruh organisasi dimana pengukuran kinerja merupakan aktifitas evaluasi secara teratur dari proses kerja para manajer, sekaligus umpan balik yang membantu pihak manajemen untuk meningkatkan kemampuan perencanaan dan pengambilan keputusan.

Secara singkat, sistem manajemen organisasional perusahaan kerajinan kulit dalam menuhi kebutuhan pasar menuntut team work yang baik. Korelasi kuat yang dibangun dalam hipotesis penelitian ini terdiri atas tiga hal utama yaitu sistem manajemen organisasional yang diharapkan mampu mendorong pengembangan sumber daya manusia yang kreatif dan inovatif sehingga akan mampu mendorong terciptanya beragam pilihan kerajinan sepatu dan tas kulit sesuai trend baru dalam pemenuhan kebutuhan pasar.

Perusahaan yang berorientasi pasar memiliki kemampuan untuk menghasilkan produksi kreatif dan inovatif untuk mengambil di posisi terdepan dalam memenuhi kebutuhan pasar atau pelanggan, sehingga perusahaan akan menawarkan produk dengan generasi yang selalu baru. Perubahan trend pasar yang cepat menuntut perusahaan untuk beradaptasi secara cepat pula dengan melakukan perbaikan kreasi dan inovasi baru. Dalam melakukan inovasi, perusahaan berusaha menciptakan nilai lebih bagi konsumen melalui penciptaan produk baru dan melakukan proses produksi yang lebih baik daripada perusahaan pesaing. Persaingan dalam waktu menggambarkan suatu peningkatan tekanan terhadap perusahaan tidak hanya untuk memperkenalkan produk baru tapi juga melakukan inovasi secara lebih cepat terhadap competitor. Perusahaan perlu mengetahui faktor-faktor yang mempengaruhi kreasi dan inovasi yang dalam hal ini dapat digunakan sebagai alat untuk memenangkan suatu persaingan (Tidd Bessant, dan Pavitt, 1998).

Sistem manajemen organisasional yang merapakan representasi team work yang akan berpengaruh, terhadap sumber daya manusia menjadi kreatif dan inovatif. Perusahaan dalam hal ini akan merespons setiap perubahan pasar dengan cepat untuk proaktif dan berani mengambil resiko untuk selalu di depan, sehingga mampu melihat orientasi pasar yang kuat untuk memenuhl pennintaan pasar demi kepuasan pelanggan (Zahra dan Covin, 1995).

Sumber daya manusia yang kreatif dan inovatif sangat penting dalam bisnis, karena kreatifitas dan inovasi baru merupakan suatu langkah yang dimaksudkan untuk membangun brand image demi kepuasan konsumen. Perusahaan wajib merespons setiap perubahan untuk menciptakan sesuatu yang baru sebagai peluang agar produk yang di hasilkan tersebut dapat diterima pasar dengan baik.

Gambar 4 merupakan model utama dalam penelitian ini. Hipotesis penelitian ini mengacu pada model tersebut yang di jelaskan dalam gambar 4. sebagai berikut: 


\section{Gambar 4}

Sistem Manajemen Organisasional akan Berpengaruh Terhadap Sumber Daya Manusia Kreatif dan Inovatif dalam Memenuhi Kebutuhan Pasar

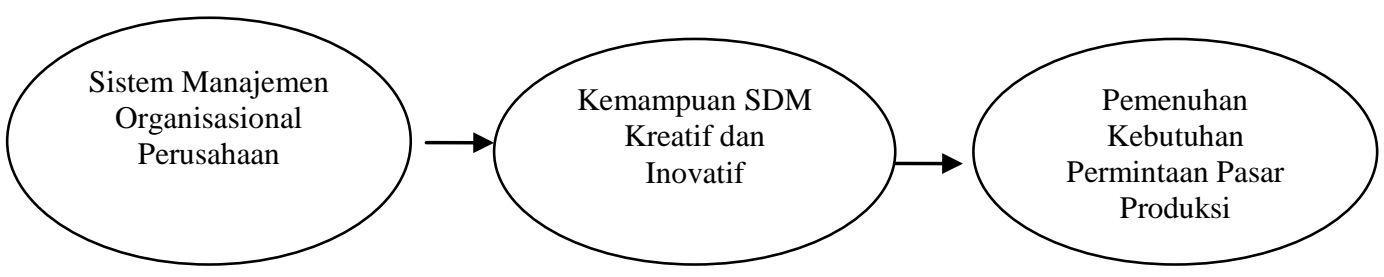

Hipotesis dalam penelitian ini adalah:

H1 : Sistem Manajemen Organisasional akan berpengaruh terhadap Sumber Daya Manusia Kreatif dan Inovatif

H2 : Sumber Daya Manusia Kreatif dan Inovatif akan berpengaruh terhadap Pemenuhan Kebutuhan Pasar

Dari dua hipotesis yang dibangun diatas, diharapkan diketahui korelasi yang sesungguhnyaantara Sistem Manajemen Organisasional Terhadap Sumber Daya Manusia Kreatif dan Inovatif dalam Memenuhi Kebutuhan Pasar.

\section{METODE PENELITIAN}

Berdasarkan bukti empiris industrikerajinan kulit di Yogyakarta, secara khususdilakukan pendekatan team work sistemmanajemen organisasional dalam perusahaan"CV D \& D Leather Handycraft" yang menampilkan pola hubungan interaksi yang melibatkan seluruh karyawan masing-masing bagian pada perusahaan tersebut.

Metode pengambilan sampel dalam penelitian ini menggunakan non probability sampling yaitu purposive sampling. Populasinya adalah seluruh karyawan perusahaan yang bekerja pada seluruh bagian perusahaan "CV D \& D Leather Handycraft".

Variabel penelitian terdiri dari variabel dependen: Sistem Manajemen Organisasional diukur dengan sistem pernyataan dan variabel independen: Sumber Daya Manusia Kreatif dan Inovatif Variabel Mediasi : Pemenuhan Kebutuhan Pasar.

Data yang digunakan adalah data primer dan data sekunder. Data primer dilakukan melalui kuesioner yang disusun dengan skala sikap Likert. Nilai jawaban dilakukan dengan skoring antara 1 sampai 5 tingkatan skalatis yang terukur darijawaban angka 5 positif atau favorable sampai jawaban angka 1 atau unfavorable. Sedangkan uji validitas memakai metode Product Moment sedangkan uni reliabilitasnya memakai metode Cronbach Alpha.

Pendistribusian kuesioner penelitian ini menggunakan metode try out terpakai, yaitu kuesioner yang terdistribusikan tanpa pre-test terlebih dahulu, sehingga seluruh data yang telah diisi responden dilakukan pengujian. Uji validitas dan reliabilitas kuesioner dilakukan dengan SPSS dengan taraf signifikansi yang digimakan dalam pengujian adalah 5\%, sehingga setiap pertanyaan mendapat status valid (sahih) jika nilai rxy positif dan nilai $\mathrm{p}<0.05$. Hasil Uji Validitas kuesioner Sistem Manajemen 
Organisasional Perusahaan diperoleh nilai rxy: struktur organisasi $(0,608)$, kebijakan $(0,575)$, gaya kepemimpinan $(0,826)$, administrasi umum $(0,701)$,sistem keuangan $(0,843)$, rekruitment $(0,813)$, komunikasi $(0,703)$ personalia $(0,853)$, peraturan kerja $(0,740)$, ketentuan jam kerja $(0,753)$, jaminan kerja $(0,643)$, sistem upah $(0,488)$,prospek karir $(0,820)$. dengan semua nilai $\quad \mathrm{p}<0,05$, sehingga semua dinyatakan valid. Dari kuesioner Kemampuan Sumber Daya Manusia Kreatif dan Inovatif, diperoleh nilai rxy: ketrampilan $(0,483)$, pengalaman $(0,673)$, pola kebiasaan $(0,639)$, pengembangan desain $(0,574)$, pemanfaatan teknologi $(0,637)$, teknik pengerjaan $(0,698)$, kecepatan $(0,578)$, kualitas $(0,707)$, standart mutu $(0,646)$, keunikan $(0,588)$ dengan semua nilai $\quad \mathrm{p}<0,05$, sehingga semua dinyatakan valid. Sedang untuk kuesioner Pemenuhan kebutuhan Permintaan Pasar Produksi: pemenuhan kebutuhan pasar/jabatan, penguasaan informasi umum, strategi pemenuhan kebutuhan pasar, seluruhnya juga dinyatakan valid.

Hasil uji reliabilitas diperoleh hasil nilai koefisien alpha: variabel Sistem Manajemen Organisasional Perusahaan (0,789), Kemampuan Sumber Daya Manusia Kreatif dan Inovatif $(0,849)$ dan Pemenuhan Kebutuhan Permintaan Pasar Produk Kulit $(0,823)$ semua di atas nilai alpha $=0,6$ sehingga semua dinyatakan reliabel.

Analisis data menggunakan Multiple Regresion untuk mengetahui sejauh mana hubungan antara variable independent (Sistem Manajemen Organisasional) atau uji-t dan variable dependent (Pemenuhan Kebutuhan Pasar) atau uji-F, Koefisien $\mathrm{R}^{2}$ menunjukkan bahwa prosentase variasi variabel dependen yang dapat dijelaskan oleh variasi yang ada dalam variabel independen. Sedangkan nilai $R^{2}$ yang berada antara nilai 0 dan nilai 1 hingga kecenderungan $\mathrm{R}^{2}$ mendekati nilai 1 berarti Sistem Manajemen Organisasional semakin baik dalam Pemenuhan Kebutuhan Pasar mempunyai hubungan yang semakin kuat

\section{HASIL PENELITIAN}

Dari seluruh kuesioner penelitian sebanyak 70 buah yang terdistribusikan melalui bagian personalia perusahaan "CV D \& D Leather Handycraft" kepada seluruh responden, dikembalikan sebanyak 65 responden. Setelah diteliti temyata 5 kuesioner tidak lengkap isinya, sehingga jumlah kuesioner yang layak diolah sebanyak 60 buah.

Dari kuesioner yang didapatkan data mengenai karakteristik responden yang seluruhnya adalah karyawan perusahaan dan dianggap cukup mewakili seluruh populasi. Responden terbanyak dilihat dari: usia adalah 21-32 tahun yaitu 32 orang $(53,33 \%)$, tingkat pendidikan adalah SMA yaitu 44 orang $(73,33 \%)$, jabatan adalah supervisor yaitu 51 orang $(80 \%)$ dan masa kerja adealah 6-9 tahun yaitu 43 orang $(71,66 \%)$.

Hasil analisis korelasi menunjukkan bahwa sistem manajemen organisasional perusahaan kulit, kemampuan sumber daya manusia kreatif dan inovatif dan pemenuhan 
kebutuhan permintaan pasar memiliki korelasi yang signifikan. Korelasi terbesar pada kemampuan sumber daya manusia kreatif dan inovatif dengan pemenuhan kebutuhan permintaan pasar produk kulit yaitu sebesar 0.532 .

Tabel 1.

Statistik Deskriptif

\begin{tabular}{|l|c|c|c|}
\hline \multicolumn{1}{|c|}{ Nama Variable } & Mean & SD & N \\
\hline Pemenuhan Kebutuhan Permintaan Pasar Produk Kulit & 25.08 & 5.07 & 60 \\
\hline Sistem Manajemen Organisasional Perusahaan & 35.60 & 5.87 & 60 \\
\hline Kemampuan sumber daya manusia kreatif dan inovatif & 23.33 & 3.55 & 60 \\
\hline
\end{tabular}

Sumber: hasil pengolahan data dengan program SPSS

Sedangkan korelasi antara variabel Sistem Manajemen Organisasional Perusahaan dan Kemampuan sumber daya manusia kreatif dan inovatif adalah sebesar 0.471 hasil lengkap perhitungan statistik deskriptif dan analisis korelasi ditunjukkan sesuai pada tabel 1 dan tabel 2 .

Tabel 2.

Korelasi Antar Variabel

\begin{tabular}{|llcc|}
\hline & $\begin{array}{l}\text { Pemenuhan } \\
\text { Kebutuhan } \\
\text { Permintaan } \\
\text { Pasar Produk } \\
\text { Kulit }\end{array}$ & $\begin{array}{l}\text { Sistem Manajemen } \\
\text { Organisasional } \\
\text { Perusahaan }\end{array}$ & $\begin{array}{l}\text { Kemampuan } \\
\text { sumber daya } \\
\text { manusia kreatif dan }\end{array}$ \\
inovatif \\
\hline $\begin{array}{l}\text { Pemenuhan } \\
\text { Kebutuhan Permintaan }\end{array}$ & 25.08 & 60 \\
$\begin{array}{l}\text { Pasar Produk Kulit } \\
\begin{array}{l}\text { Sistem Manajemen } \\
\text { Organisasional Perusahaan }\end{array}\end{array}$ & 35.60 & 5.07 & 60 \\
\hline $\begin{array}{l}\text { Kemampuan sumber } \\
\text { manusia kreatif } \\
\text { dan inovatif }\end{array}$ & 23.33 daya & 5.87 & 60 \\
\hline
\end{tabular}

*. Korelasi signifikan pada level 0.01 (2-tailed)

Sumber: Hasil pengolahan data dengan program SPSS

Sedangkan hasil analisis pengaruh variabel independen terhadap variabel dependen dengan menggunakau multiple regression dapat dilihat dari tabel 3.

Tabel 3.

Hasil Analisis Multiple Regression

\begin{tabular}{|l|c|c|c|}
\hline \multicolumn{1}{|c|}{ Variable } & Beta & t & p \\
\hline Sistem Manajemen Organisasional Perusahaan & 0.220 & 2.763 & 0.008 \\
\hline $\begin{array}{l}\text { Pemenuhan Kebutuhan Permintaan Pasar } \\
\text { Produk Kulit }\end{array}$ & 0.250 & 3.628 & 0.001 \\
\hline
\end{tabular}

Sumber: Hasil pengolahan data dengan program SPSS 
Berdasarkan hasil analisis regresi berganda, dengan Uji-F dan uji-t menunjukkan bahwa variabel Sistem Manajemen Organisasional Perusahaan, sistem administrasi manajemen, kemampuan sumber daya manusia kreatif dan inovatif dalam Pemenuhan Kebutuhan Permintaan Pasar Produk Kulit, secara uji bersama maupun uji parsial memiliki pengaruh yang signifikan Sistem Manajemen Organisasional Perusahaan terhadap pengembangan sumber daya manusia yang kreatif dan inovatif. Hasil positifsignifikansinya $(\mathrm{F}=16.563 ; \mathrm{p}=00.00)$. Melalui uji-t maka pengaruh antara Sistem Manajemen Organisasional Perusahaan terhadap pengembangan sumber daya manusia yang kreatif dan inovatif adalah positif signifikan ( $\mathrm{t}=2.763 ; \mathrm{p}-0.008$ ), demikian jugadengan pengembangan sumber daya manusia yang kreatif dan inovatif terhadap Pemenuhan Kebutuhan Permintaan Pasar Produk Kulit adalah positif dan signifikan $(\mathrm{t}=3.628 ; \mathrm{p}-0.001)$.

Sedangkan nilai $\mathrm{R}^{2}$ yang didapatkan adalah sebesar 0.368 , menunjukkan bahwa 36.8\% variasi dalam variabel Pemenuhan Kebutuhan Permintaan Pasar Produk Kulit dapat dijelaskan oleh variabel Sistem Manajemen Organisasional Perusahaan dan variabel Kemampuan Sumber Daya Manusia yang Kreatif dan Inovatif.

\section{PEMBAHASAN}

Berdasarkan analisis penelitian dapat diterangkan bahwa tingkat korelasi antara tiga variabel yang terdiri dari variabel Sistem Manajemen Organisasional Perusahaan memiliki pengaruh yang kuat terhadap pengembangan sumber daya manusia yang kreatif dan inovatifsehingga menghasilkan produktifitas yang tinggi yang sangat menunjang dalam Pemenuhan Kebutuhan Permintaan Pasar Produk Kulit.

Dari hasil pengujian hipotesis yang dilakukan ternyata menunjukkan dukungan terhadap kedua hipotesis penelitian. Hipotesis pertama penelitian, yang menyatakan bahwa Sistem Manajemen Organisasional akan berpengaruh terhadap Sumber Daya Manusia Kreatif dan Inovatif didukung.

Demikian juga dengan hipotesis kedua penelitian, yang menyatakan bahwa Sumber Daya Manusia Kreatif dan Inovatif akan berpengaruh terhadap Pemenuhan Kebutuhan Pasar, dinyatakan didukung.

Dengan demikian, hubungan tiga variabel dalam penelitian ini memiliki interdependensi yang sangat tinggi dimana sistem informasi pasar dalam bentuk trend pasar sebagai factor eksternal akan terkait erat dengan factor internal produksi sehingga dapat saling melengkapi. Pemenuhan Kebutuhan Permintaan Pasar Produk Kulit akan bertahan bilamana ada interelasi yang baik dalam Sistem Manajemen Organisasional Perusahaan, Sistem Administrasi Manajemen memiliki kohesifitas yang tinggi untuk mendorong kemampuan Sumber Daya Manusia yang Kreatif dan Inovatif, sehingga mampu Pemenuhan Kebutuhan Pasar. 


\section{KESIMPULAN DAN SARAN}

1. Kesimpulan

Hasil analisis regresi menunjukkan bahwa pengaruh "Kebijakan Sistem Manajemen Organisasional Perusahaan Kerajinan Kulit" cukup signifikan terhadap "Peningkatan Sumber Daya Manusia yang Kreatif dan Inovatif yang ditujukkan score $(\mathrm{t}=2.763 ; \mathrm{p}=0,008)$ dengan demikian kebijakan sistem manajemen perusahaan dengan model pengembangan staf kreatif dan inovatif walaupun menuntut kejelasan penghargaan maupun promosi jabatan adalah langkah yang sangat tepat, sesuai dengan tuntutan kebutuhan ketenagakerjaan di perusahaan.

Hasil analisis regresi menunjukkan bahwa "Pengembangan Sumber Daya Manusia yang Kreatif dan Inovatif' memiliki signifikansi yang kuat terhadap "Pemenuhan Kebutuhan Permintaan Pasar Produk Kulit" yang ditujukkan score $\quad(\mathrm{t}=$ 3.628 ; p - 0,001) hal ini meagindikasikan bahwa langkah pengembangan sumber daya manusia agar kreatif dan inovatif merupakan langkah yang tepat untuk mampu berkolaborasi untuk menciptakan produk baru sehingga dapat menjadi modal strategis untuk memenuhi kebutuhan konsumen sesuai trend pasar yang baru.

Berdasarkan koefisien determinan $\mathrm{R}^{2}$ sebesar 0,368 menunjukkan bahwa $36.8 \%$ variasi dalam variabel "Sistem Manajemen Organisasional Perusahaan Kerajinan Kulit" memiliki signifikansi yang kuat terhadap variabel "Pemenuhan Kebutuhan Permintaan Pasar Produk" teiapi akan tidak baik bila mengabaikan "Variabel Kemampuan Sumber. Daya Manusia yang Kreatif dan Inovatif karena secara uji signifikansinya cukup kuat.

Dari beberapa hasil pengamatan peneliti masih dijumpai jabatan rangkap pada pimpinan perusahaan yang merangkap sebagai kepala produksi, walaupun disadari oleh pimpinan perusahaan itu sifatnya sementara saja. Namun bila mengacu pada tata organisasi yang baik, sebaiknya hal tersebut dihindarkan walaupun sifatnya sementara waktu.

\section{Saran}

Beberapa saran penelitian yang perlu mendapat perhatian kita adalah bahwa budaya dan karakter, bisnis dalam masyarakat perlu ditumbuhkan, tidak terjebak oleh rutinitas, karena banyak UMKM yang mengalami kesulitan karena tidak memiliki kemampuan adaptive terhadap perubahan trend pasar yang sangat dinamis, sehingga pelaku bisnis dalam hal ini perlu mengembangkan kreasi dan inovasi baru guna mengikuti trend pasar.

Berdasarkan proses penelitian yang dilakukan di Perusahaan Kerajinan Kulit "CV D \& D Leather Handycraft" peneliti memberilcan saran terhadap rangkap jabatan walaupun sifatnya sementara menunggu kepala bagian produksi yang baru, yang masih dalam tahap rekruitmen di perusahaan tersebut, sebaiknya dihindari karena konsekuensi 
dan rangkap jabatan antara fungsi manajer dengan bagian kepala produksi bila ditangani oleh satu orang kedepan akan sangat berisiko.

\section{DAFTAR PUSTAKA}

Cronin, Jr., J.J., Brady, M.K., \& Hurt, G.T.M., 2000, "Assessing the Effect of Quality, Value, and Customer Satisfaction in Consumer Behavioral Intentions in Service Environments", Journal of Retailing, 76(2), pp. 193-218.

Dirk C. Moosmayer, Alexandra Fuljahn, 2010, "Consumer Perceptions of Cause Related Marketing Campaigns", Journal of Consumer Marketing, Vol. 27 Iss: 6, pp.543 549

Eddy. MiSusanto, 2003 "Hubungan Antara Tempsramen Karyawan, Pemberian Kompensasi dan Jenjang Karier Prestasi Kerja Karyawan," Jurnal Manajemen dan Kewirausahaan, vol.5, No.I; pp. $42-55$

Frismar, J. And Horte, S.A 2005, "Managing External Information in Manufactur Firms: The .Implementation as a Core Competency: The 5P's model". Journal of management Research, 7(1), pp. 3-17

H. Teman Koesmono, 2005, "Pengaruh Budaya Organisasi terhadap Motivasi dan Kepuasan

Kerja Serta Kinerja Karyawan pada Sub Sektor Industri Pengolahan Kayu Skala Menengah di Jawa Timur", Jurnal Manajemen dan Kewirausahaan Vol. 7 No. 2; pp. $171-188$

Mengue, N. and S, Auh. 2006., "Creating a Firm-Level Dynamic Capability Through Capitalizing on Market Orientation and Innovativeness". Journal of The Academy of Marketing Science, 24, pp. 63-73

Miyazaki, A., Grewal, D. \& Goodstein, R, 2005, "The Effect of Multiple Extrinsic Cues on Quality Perceptions; A Matter of Consistency". Journal of Consumer Research, Vol. 32, pp. 146-153

Piyor, M. G., Anderson, D., Toombs, L., \& Humphreys, J, H., 2007, "Strategic Impact on Innovation Performance". Journal of Innovatidn Management 22 (3); pp. 251266

Tjiptono, Fandy, 2005, Brand Management \& Strategy. Penerbit Andi. Yogyakarta 